\title{
Effects of dietary protein and water exchange on water quality, survival and growth of postlarvae and juvenile Litopenaeus vannamei
}

\author{
Lan-mei Wang ${ }^{\mathrm{a}, \mathrm{b}}$, Addison Lee Lawrence ${ }^{\star \mathrm{b}}$, Frank Castille ${ }^{\mathrm{b}}$, and Yun-long Zhao ${ }^{\mathrm{a}}$ \\ ${ }^{a}$ Life Science College, East China Normal University, Shanghai 200062, China \\ ${ }^{\mathrm{b}}$ Texas AgriLife Research Mariculture Laboratory at Port Aransas, Texas A \& M University, Port Aransas, TX 78373 , \\ USA
}

\begin{abstract}
A B S T R A C T
Two growth trials were conducted with Litopenaeus vannamei to evaluate effects of dietary protein and water exchange on survival, growth and water quality. In both trials, protein levels were 12, 15, 20, 26 and $35 \%$. In the first trial, $6.21 \mathrm{~g}$ juvenile shrimp were stocked for 23 days at either zero or high $(2750 \%$ daily) water exchange. At high exchange, survival was greater than $93 \%$ for all protein levels. Final body weight (FBW) and weight gain (WG) increased with protein level from $12 \%$ to $20 \%(P<0.05)$. FBW and WG at 20 and $26 \%$ protein were lower than that at $35 \%$ protein. At zero exchange, survival decreased with protein above $20 \%$. At zero exchange, water quality decreased (high ammonia, nitrite, nitrate and low $\mathrm{pH}$, alkalinity) with protein greater than $15 \%$. WG with $12 \%$ protein was greater at zero exchange than at high exchange.

In the second trial, $0.22 \mathrm{~g}$ postlarvae were stocked for 26 days at either zero or high ( $5440 \%$ daily) water exchange. At high exchange, survival was $90 \%$ or greater for all protein levels. FBW and WG increased with protein level from $12 \%$ to $20 \%(P<0.05)$. At zero exchange, FBW and WG were maximum with $20 \%$ protein. Survival was lowest at $35 \%$ protein. For $35 \%$ protein, survival was lower at zero than at high exchange. For all protein levels except $35 \%$, WG was higher at zero than at high exchange.

The results suggest that lower protein diets can replace high protein $(35 \%)$ commercial diets and obtain high growth rate for both juvenile and postlarvae L. vannamei at zero exchange. Further, a $20 \%$ protein diet, which contained $25.3 \%$ marine animal meals, was adequate for shrimp growth, survival and water quality at zero exchange.
\end{abstract}

Keywords: Litopenaeus vannamei, Dietary protein level, Zero-water exchange, Survival, Growth, Water quality.

\section{Introduction}

Aquaculture production of L. vannamei is currently limited by its environmental impact, the incidence of disease and the availability and quality of protein in dietary ingredients used in shrimp diets (Browdy et al., 2001; De Schryver et al., 2008; Hopkins et al., 1995). The quality of protein in diets is a major factor in growth, diet cost and water quality during shrimp production (Bender et al., 2004; Kureshy and Davis, 2002). Ingredients containing protein are the most expensive items in shrimp diets. The cost of diets represents at least $50 \%$ of total aquaculture production costs (Bender et al., 2004). Optimum levels of dietary protein for L. vannamei have been reported to be $34 \%$ in shrimp stocked at $0.09 \mathrm{~g}$ (Hu et al., 2008) and probably higher

\footnotetext{
* Present address: 1300 Port Street, Port Aransas, Texas 78373, USA. Tel.:+1 361749 4625; fax: +1 361749 5756. Email address: smpall@yahoo.com
}

than $32 \%$ in shrimp stocked at 1.3 to $1.4 \mathrm{~g}$ (Kureshy and Davis, 2002). Shrimp diets represent the major contribution of pollutants in effluent water (Lawrence et al., 2001), and dietary protein is the main source of nitrogenous wastes in shrimp culture systems (Moeckel et al., 2012). However, elimination of toxic nitrogenous wastes in culture systems by water exchange can be limited by both the availability of water and potential environmental effects of nitrogenous waste in effluents. In addition, reduced water exchange at some culture locations has been necessitated by the presence of disease pathogens in surrounding waters.

These challenges to production have led to development of zero water exchange shrimp culture technology. Generally present in zero water exchange systems, are suspended particles, which consist of a variety of microbes, microalgae, protozoa and other organisms together with detritus and dead organic matter (Avnimelech, 2012; Moeckel et al., 2012). These 
particles are collectively known as biofloc. Heterotrophic bacteria in biofloc can lower levels of ammonium and nitrite in culture systems (Asaduzzaman et al., 2008; Crockett et al., 2013). Biofloc can also indirectly control pathogenic bacteria by reducing infection and the spread of diseases through reduced water exchange (Cohen et al., 2005; Horowitz and Horowitz, 2001). Biofloc can improve production by providing a food source for shrimp and provide economic benefits by decreasing diet requirements (Browdy et al., 2001; De Schryver et al., 2008; Hopkins et al., 1995). Biofloc can be consumed by shrimp and may lower the dietary protein levels required for production (Burford et al., 2003; 2004; Crab et al., 2010; Hari et al., 2004; 2006; Wasielesky et al., 2006; Xu et al., 2012a). Velasco and Lawrence (2000) reported that growth of L. vannamei postlarvae was greater in static culture system than that in recirculating system for diets containing $18 \%$ and $25 \%$ protein. $\mathrm{Xu}$ et al. (2012a) also reported that the protein level of diet for $L$. vannamei juveniles could be reduced to $25 \%$ without affecting shrimp growth in a zero-water exchange biofloc-based system. Additionally, differences in weight gain and survival of $L$. vanname $i$ were not observed when feeding commercial diets with $25 \%, 30 \%, 35 \%$ and $40 \%$ protein in a zero-water exchange system (Gómez-Jiménez et al., 2005).

Reduction of fish meal has become a high priority in the formulation of shrimp diets. Surprisingly, reduction of marine animal meals in shrimp diets has not been reported with zero-water exchange culture systems.

Although the zero-water exchange biofloc technology for shrimp production has been studied and developed, much is still unknown, particularly, management and maintenance of optimum biofloc levels and populations. With respect to shrimp growth and survival and water quality, little information exists on the interaction of effects of water exchange and shrimp size, and on the interaction of effects of water exchange and shrimp dietary protein level. This study was conducted to investigate the effects of dietary protein level (12 to 35\%) on growth and survival of shrimp at either zero or high water exchange in growth trials stocked with two sizes of shrimp, postlarvae and 6 g juvenile shrimp. In addition, this study provides information on the effects of water exchange and dietary protein level on culture tank water quality for two different sizes of shrimp.

\section{Materials and Methods}

\subsection{Experimental diets}

Five semi-purified diets with crude protein levels of 12, 15, 20, 26 , and $35 \%$ were used in two separate experiments. Ingredient compositions and calculated nutrient levels for the experimental diets are shown in Tables 1 and 2, respectively. Crude protein levels were varied by replacing appropriate amounts of the squid muscle meal, fish meal and soy protein isolate in the $35 \%$ protein diet with wheat starch. Amounts of calcium diphosphate, diatomaceous earth, potassium chloride, sodium chloride, calcium carbonate, fish oil, soybean oil and methionine were varied so that total ash, crude fiber, crude lipid, marine oil, non-marine oil, methionine, copper, zinc, calcium, sodium, magnesium and potassium varied less than $2 \%$ in all diets. As crude protein levels increased from 12 to $35 \%$, calculated levels of protein from marine sources increased from 12 to $30 \%$, calculated energy levels increased from $3702 \mathrm{cal} / \mathrm{g}$ to $4021 \mathrm{cal} / \mathrm{g}$ and calculated carbohydrate levels decreased from $51 \%$ to $28 \%$. Dry ingredients, including the binder, were mixed for a minimum of 40 minutes. Soybean and menhaden fish oils were gradually added and mixed for an additional 30 minutes. Water (40\% of dry ingredients) was added to other mixed ingredients to form a dough, and then immediately extruded at room temperature through a $2 \mathrm{~mm}$ die using a Hobart A200 extruder (Hobart Corporation, Troy, New Jersey, USA). Extruded diets were dried at $25^{\circ} \mathrm{C}$ for $24 \mathrm{~h}$ and then milled and sieved to obtain appropriate sizes for automatic feeders and the size of shrimp (Table 3). All diet was stored at $-10^{\circ} \mathrm{C}$ in sealed plastic bags until the day of use.

\subsection{Shrimp}

Two experiments were conducted using different sizes of shrimp. The first experiment was stocked with juvenile shrimp and the second with postlarvae. Juvenile $L$. vannamei were reared at the Texas A\&M AgriLife Research Mariculture Laboratory (Port Aransas, Texas, USA) from postlarvae obtained from Shrimp Improvement System, Inc. (Islamorada, Florida, USA). Shrimp were fed a commercial diet (Zeigler Bros. Inc., Gardners, PA, USA) until stocked in the growth trials.

\subsection{Experimental systems}

\section{3..1. Juvenile shrimp}

In the first experiment, juvenile shrimp were stocked into tanks (bottom area $0.3 \mathrm{~m}^{2}$, depths $0.3 \mathrm{~m}$ ) for a 23-day growth trial. Water in each tank was aerated with a single $5 \times 2.5 \times 2.5 \mathrm{~cm}$ air-stone to keep dissolved oxygen (DO) above $5 \mathrm{mg} / \mathrm{l}$ without water exchange, and to keep biofloc particles suspended. Aeration volume was $10 \mathrm{~L} \mathrm{min-1}$ at a depth of $0.3 \mathrm{~m}$. Treatments in the experiment included two independent variables, dietary protein levels $(12,15,20,26$, and $35 \%)$ and water exchange (zero exchange and high exchange). Reverse osmosis water was added to replace evaporation in zero exchange tanks. Water in high exchange tanks consisted of treated (mechanical and biological filtration) water from a recirculating seawater system. Exchange of seawater in the culture tanks was $2750 \%$ per day. Each treatment contained three replicate tanks. Fifteen shrimp were randomly stocked into each tank, which was equivalent to 45 shrimp per $\mathrm{m}^{2}$ or 150 shrimp per $\mathrm{m}^{3}$. A photoperiod of $12-\mathrm{h}$ light and 12-h dark was used. 


\begin{tabular}{|c|c|c|c|c|c|}
\hline \multirow[t]{2}{*}{ Ingredients } & \multicolumn{5}{|c|}{ Diet protein (\% as fed basis) } \\
\hline & 12 & 15 & 20 & 26 & 35 \\
\hline Squid muscle meal ${ }^{\mathrm{b}}$ & 12.20 & 15.60 & 19.30 & 25.90 & 30.00 \\
\hline Fish meal, menhaden ${ }^{\mathrm{c}}$ & 2.50 & 3.00 & 6.00 & 7.00 & 8.00 \\
\hline Soy protein isolate ${ }^{\mathrm{b}}$ & 0.00 & 0.00 & 0.00 & 0.00 & 5.70 \\
\hline Wheat starch ${ }^{\mathrm{a}}$ & 54.00 & 50.70 & 45.10 & 38.40 & 28.50 \\
\hline Methionine $^{\mathrm{h}}$ & 0.30 & 0.20 & 0.20 & 0.10 & 0.00 \\
\hline Menhaden fish oil ${ }^{\mathrm{C}}$ & 2.20 & 1.90 & 1.40 & 0.93 & 0.60 \\
\hline Soybean oil ${ }^{\mathrm{a}}$ & 0.70 & 0.70 & 0.70 & 0.67 & 0.60 \\
\hline Diatomaceous earth ${ }^{\mathrm{a}}$ & 3.40 & 3.40 & 3.40 & 3.60 & 4.00 \\
\hline Calcium diphosphate $^{\mathrm{a}}$ & 7.40 & 7.00 & 6.70 & 6.10 & 5.60 \\
\hline Calcium carbonate $^{\mathrm{a}}$ & 0.80 & 1.00 & 0.90 & 1.20 & 1.40 \\
\hline Potassium chloride, reagent grade & 2.30 & 2.30 & 2.20 & 2.10 & 1.90 \\
\hline Sodium chloride, reagent grade ${ }^{a}$ & 1.70 & 1.70 & 1.60 & 1.50 & 1.20 \\
\hline Lecithin, dry,95\% ${ }^{\mathrm{f}}$ & 4.00 & 4.00 & 4.00 & 4.00 & 4.00 \\
\hline Cellulose $^{\mathrm{e}}$ & 3.20 & 3.20 & 3.20 & 3.20 & 3.20 \\
\hline Alginate $^{\mathrm{d}}$ & 3.00 & 3.00 & 3.00 & 3.00 & 3.00 \\
\hline Magnesium oxide $^{a}$ & 1.60 & 1.60 & 1.60 & 1.60 & 1.60 \\
\hline Vitamin-mineral premix ${ }^{\mathrm{b}}$ & 0.46 & 0.46 & 0.46 & 0.46 & 0.46 \\
\hline Cholesterol $^{f}$ & 0.20 & 0.20 & 0.20 & 0.20 & 0.20 \\
\hline Stable vitamin $\mathrm{C}^{\mathrm{b}}$ & 0.04 & 0.04 & 0.04 & 0.04 & 0.04 \\
\hline
\end{tabular}

${ }^{a}$ MP Biomedicals, Solon, Ohio, USA.

b Zeigler Brothers, Gardners, Pennsylvania, USA.

'Omega Protein, Houston, Texas, USA.

d TICA-alginate 400, medium viscosity sodium alginate.TIC GUMS, White Marsh, Maryland, USA.

e Sigma-Aldrich Chemical, St. Louis, Missouri, USA.

${ }_{\mathrm{f}}^{\mathrm{A}}$ ADM, Decatur, Illinois, USA.

g VWR, Chester, Pennsylvania, USA.

${ }^{\text {h }}$ Evonik, Brampton, Ontario, Canada. 


\begin{tabular}{lccccc}
\hline Nutrients & \multicolumn{5}{c}{ Diet protein (\% as fed basis) } \\
\cline { 2 - 6 } & 12 & 15 & 20 & 26 & 35 \\
\hline Crude protein & 12.0 & 15.0 & 20.0 & 26.0 & 35.0 \\
Crude protein, marine sources & 12.0 & 15.0 & 20.0 & 26.0 & 30.0 \\
Carbohydrate & & & & & \\
Ash & 51.4 & 48.4 & 43.3 & 37.6 & 28.5 \\
Crude lipid & 18.1 & 18.0 & 18.1 & 18.1 & 18.1 \\
Crude fiber & 8.08 & 8.04 & 8.06 & 8.08 & 8.06 \\
Gross energy (cal g ${ }^{-1}$ ) & 3.26 & 3.26 & 3.26 & 3.26 & 3.28 \\
\hline
\end{tabular}

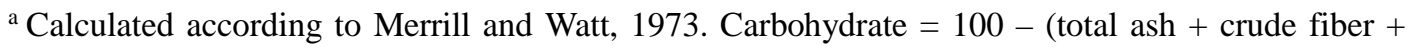
moisture + crude lipid + crude protein).

Table 2. Calculated nutrient compositions of experimental diets (\%).

\section{3..2. Postlarvae}

In the second experiment, postlarval shrimp were stocked in tanks (bottom area $0.1 \mathrm{~m}^{2}$, depth $0.2 \mathrm{~m}$ ) for a 26-day growth trial. Water in each tank was aerated with a single $4 \times 2 \times 2 \mathrm{~cm}$ air-stone to keep dissolved oxygen (DO) above $5 \mathrm{mg} / \mathrm{l}$ without water exchange, and to keep biofloc particles suspended. Aeration volume was $1 \mathrm{~L} \mathrm{~min}-1$ at a depth of $0.2 \mathrm{~m}$. Treatments were the same as first experiment. Water in high exchange tanks consisted of treated (mechanical, biological filtration and ultraviolet sterilizer) water from a recirculating seawater system. Exchange of seawater in the culture tanks was $5440 \%$ per day. Each treatment contained six replicate tanks. Ten shrimp were randomly stocked into each tank, which was equivalent to 100 shrimp per $\mathrm{m}^{2}$ or 500 shrimp per $\mathrm{m}^{3}$. All other conditions were identical to those described for experiment 1 .

\subsection{Growth trials}

For the two growth trials, average weights at stocking (IBW) were $6.21 \mathrm{~g} \pm 0.22(\mathrm{SD})$ for $N=30$ and $0.22 \mathrm{~g} \pm 0.02$ (SD) for $N=60$, respectively. Within experiments, differences between treatments were not significant $(P=0.7418$ and $P=0.3945$, respectively). Automatic feeders fed shrimp 15 times daily to slight excess. Uneaten diet and wastes were removed daily before filling feeders at high exchange to minimize natural produc- tivity. Feeding rates and feed particle sizes are shown in Table 3.

\subsection{Water quality monitoring}

During the experimental period, water temperature, salinity, and DO were measured daily in different culture tanks at each water exchange rate with an YSI 85 oxygen/conductivity instrument (YSI, Yellow Springs, Ohio, USA). Total ammonia nitrogen (TAN), nitrite nitrogen $\left(\mathrm{NO}_{2}-\mathrm{N}\right)$, nitrate nitrogen $\left(\mathrm{NO}_{3}-\mathrm{N}\right), \mathrm{pH}$ and alkalinity $(\mathrm{KH})$ were measured once a week in three replicate tanks at each protein level for zero exchange and in one replicate tank at each protein level for high exchange. TAN, $\mathrm{NO}_{2}-\mathrm{N}$ and $\mathrm{NO}_{3}-\mathrm{N}$ were measured with a Hach DR/2100 spectrophotometer (Hach, Loveland, Colorado, USA) following the Standard methods for the examination of water and wastewater (APHA, 2005). $\mathrm{pH}$ was measured with a pH52 meter (Milwaukee Instruments, Rocky Mount, North Carolina, USA). KH was measured by buret titration method (APHA, 2005).

\subsection{Calculations and statistics}

At the end of feeding trial, the number and final group weight of surviving shrimp were recorded for 


\begin{tabular}{|c|c|c|c|c|}
\hline \multirow[b]{2}{*}{ Day } & \multicolumn{2}{|c|}{ Juvenile shrimp } & \multicolumn{2}{|c|}{ Postlarvae } \\
\hline & Feed/shrimp (g) & Feed size $^{1}$ & Feed/shrimp (g) & Feed size $^{1}$ \\
\hline 1 & 0.60 & $12 / 7$ & 0.084 & $20 / 18$ \\
\hline 2 & 0.60 & $12 / 7$ & 0.103 & $18 / 14$ \\
\hline 3 & 0.60 & $12 / 7$ & 0.122 & $18 / 14$ \\
\hline 4 & 0.63 & $12 / 7$ & 0.140 & $18 / 14$ \\
\hline 5 & 0.63 & $12 / 7$ & 0.159 & $18 / 14$ \\
\hline 6 & 0.66 & $12 / 7$ & 0.178 & $14 / 12$ \\
\hline 7 & 0.66 & $12 / 7$ & 0.187 & $14 / 12$ \\
\hline 8 & 0.66 & $12 / 7$ & 0.187 & $14 / 12$ \\
\hline 9 & 0.66 & $12 / 7$ & 0.193 & $14 / 12$ \\
\hline 10 & 0.69 & $12 / 7$ & 0.193 & $14 / 12$ \\
\hline 11 & 0.69 & $12 / 7$ & 0.211 & $14 / 12$ \\
\hline 12 & 0.72 & $12 / 7$ & 0.211 & $14 / 12$ \\
\hline 13 & 0.73 & $12 / 7$ & 0.211 & $14 / 12$ \\
\hline 14 & 0.80 & $12 / 7$ & 0.232 & $14 / 12$ \\
\hline 15 & 0.84 & $12 / 7$ & 0.232 & $14 / 12$ \\
\hline 16 & 0.84 & $12 / 7$ & 0.232 & $14 / 12$ \\
\hline 17 & 0.84 & $12 / 7$ & 0.232 & $14 / 12$ \\
\hline 18 & 0.84 & $12 / 7$ & 0.255 & $14 / 12$ \\
\hline 19 & 0.88 & $12 / 7$ & 0.255 & $12 / 7$ \\
\hline 20 & 0.88 & $12 / 7$ & 0.255 & $12 / 7$ \\
\hline 21 & 0.91 & $12 / 7$ & 0.280 & $12 / 7$ \\
\hline 22 & 0.91 & $12 / 7$ & 0.280 & $12 / 7$ \\
\hline 23 & 0.96 & $12 / 7$ & 0.280 & $12 / 7$ \\
\hline 24 & & & 0.308 & $12 / 7$ \\
\hline 25 & & & 0.308 & $12 / 7$ \\
\hline 26 & & & 0.353 & $12 / 7$ \\
\hline
\end{tabular}

${ }^{1}$ Feed between upper sieve number / below sieve number. U.S.A. Standard Testing Sieve. A.S.T.M.E11 Specification. No.20: Opening micrometer $850 \mu \mathrm{m}$. No.18: Opening millimeter $1.00 \mathrm{~mm}$. No.14: Opening millimeter $1.40 \mathrm{~mm}$. No.12: Opening millimeter 1.70mm. No.7: Opening millimeter $2.80 \mathrm{~mm}$.

Table 3. Feeding rates and feed particle sizes for both growth trials.

each culture tank. Performance parameters were final body weight (FBW), weight gain (WG) and survival. $F B W=$ total weight/number of surviving shrimp, $W G=F B W-I B W$ and $\operatorname{Survival}(\%)=100 \times$ (number of surviving shrimp/number of stocked shrimp).

Temperature, salinity and DO were compared between high and zero exchange by one-way ANOVA. For each sample day, TAN, $\mathrm{NO}_{2}-\mathrm{N}, \mathrm{NO}_{3}-\mathrm{N}, \mathrm{pH}$ and $\mathrm{KH}$ were analyzed using one-way ANOVA by protein in zero exchange. Calculated growth and survival parameters were analyzed using two-way ANOVA. Where interactions between dietary protein levels and water exchange were significant $(P<0.05)$, parameters were 

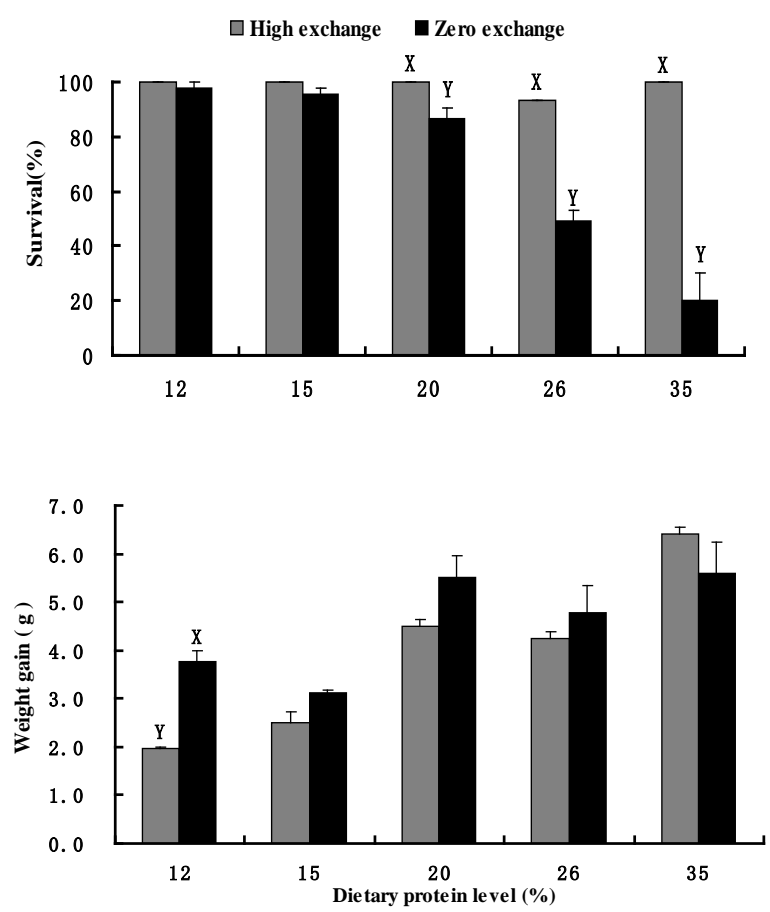

Fig. 1. Effects of dietary protein and water exchange on survival and weight gain (WG) for 23 day growth trial with juvenile shrimp stocked at $6.21 \mathrm{~g} \pm 0.22$ (SD). Values represent means \pm SE for 3 replicates. Significant differences between water exchange within each level of protein are indicated with different letters (One-way ANOVA, SNK $P<0.05$ ).

analyzed by one-way ANOVA by both protein for the effects of exchange and by exchange for the effects of protein. For both water exchange rates where one-way ANOVA indicated that differences among protein levels were significant $(P<0.05)$, Student-Newman-Keuls (SNK) multiple range tests were used to determine differences between protein levels. All statistical analyses were performed using the SAS microcomputer software package v9.3 (SAS Institute, Cray, North Carolina, USA).

\section{Results}

\subsection{Juvenile shrimp}

\section{1..1. Shrimp performance}

FBW, WG and survival of $L$. vannamei fed the five diets at high and zero exchange are given in Table 4 and Fig. 1 for the growth trial stocked with juvenile shrimp. For all parameters, the interaction between dietary protein level and water exchange was significant $(P \leqslant 0.0131)$. A posteriori comparisons of means between protein levels within water exchange are shown in Table 4. A posteriori comparisons of means between water exchange rates within protein levels are shown in Fig. 1.
At high exchange, survival was high $(\geqslant 93.3 \%)$ for all protein levels. At zero exchange, survival did not differ between 12,15 , and $20 \%$ protein $(97.8,95.6$ and $86.7 \%$, respectively), but decreased to $48.9 \%$ with $26 \%$ protein, and to $20.0 \%$ with $35 \%$ protein (Table 4 ). For protein levels greater than $15 \%$, survival was lower at zero exchange than at high exchange (Fig. 1).

At high exchange, growth (FBW and WG) increased with dietary protein with the exception of 20 and $26 \%$ protein where growth did not differ (Table 4). At zero exchange, growth was greater for 20 to $35 \%$ protein than 12 and $15 \%$ protein. Growth did not differ between 12 and $15 \%$ protein or between 20 to $35 \%$ protein. WG with $12 \%$ protein was greater at zero exchange than at high exchange (Fig. 1).

\section{1..2. Water quality}

DO was lower $(P<0.0001)$ in zero exchange treatments (mean \pm standard deviation of $5.13 \pm 0.19 \mathrm{mg} / \mathrm{l}, n=110$ ) than in high exchange treatments $(5.58 \pm 0.23 \mathrm{mg} / \mathrm{l}, n=22)$. Salinity was higher $(P<0.0001)$ in zero exchange treatments $(38.6 \pm 0.3 \mathrm{ppt}, n=110)$ than in high exchange treatments $(37.0 \pm 1.4 \mathrm{ppt}, n=22)$. Temperature was lower $(P<0.0001)$ in zero exchange treatments $\left(28.2 \pm 0.3{ }^{\circ} C, n=110\right)$ than in high exchange treatments $\left(29.4 \pm 0.9{ }^{\circ} C, n=22\right)$. Though there were differences in DO, salinity and temperature between the high and zero exchange treatments, all means were within acceptable levels for growth and survival.

At zero exchange, weekly means and standard errors of TAN, $\mathrm{NO}_{2}-\mathrm{N}$ and $\mathrm{NO}_{3}-\mathrm{N}$ are shown in Fig. 2 for each level of protein. In addition, water quality differences between diets were not significant at high exchange. Values for all protein levels at high exchange were pooled and shown as high exchange in Fig. 2. At zero exchange, TAN increased from day 4 through 22 for both 26 and $35 \%$ protein. For high exchange and protein levels of 12 to $20 \%$ at zero exchange, TAN levels remained below $0.08 \mathrm{mg} / \mathrm{l}$ through 22 days. At zero exchange, $\mathrm{NO}_{2}-\mathrm{N}$ levels increased to a maximum at day 22 for all protein levels. At protein levels of 20 to $35 \%$ protein at zero exchange, $\mathrm{NO}_{2}-\mathrm{N}$ levels ranged from 8.70 to $9.23 \mathrm{mg} / \mathrm{l}$ at day 22 . At high exchange and $12 \%$ protein at zero exchange, $\mathrm{NO}_{2}-\mathrm{N}$ levels remained below $0.39 \mathrm{mg} / \mathrm{l}$. At zero exchange, $\mathrm{NO}_{3}-\mathrm{N}$ levels increased for all protein levels. For protein levels of 26 and $35 \%$ at zero exchange, $\mathrm{NO}_{3}-\mathrm{N}$ levels did not differ between days 18 and 22. At day 22, $\mathrm{NO}_{3}-\mathrm{N}$ levels ranged from 87.00 to $101.56 \mathrm{mg} / \mathrm{l}$ for all protein levels at zero exchange.

Means and standard errors of $\mathrm{pH}$ and $\mathrm{KH}$ are shown in Fig. 3 for each protein level at zero exchange. Water quality differences between diets were not significant at high exchange. Values for all protein levels at high exchange were pooled and shown as high exchange in Fig. 3. During the growth trial, $\mathrm{pH}$ decreased for 26 and $35 \%$ protein levels at zero exchange. At day $22, \mathrm{pH}$ at zero exchange was 7.23 for $26 \%$ protein and 6.87 for $35 \%$ protein. For high exchange and other protein levels at 


\begin{tabular}{|c|c|c|c|c|}
\hline Water exchange & Protein (\%) & FBW $(g)^{1}$ & WG $(g)^{1}$ & Survival (\%) \\
\hline & 12 & $8.15 \pm 0.11^{\mathrm{D} 2}$ & $1.97 \pm 0.04^{\mathrm{D} 2}$ & $100 \pm 0.00^{\mathrm{A} 2}$ \\
\hline \multirow[t]{5}{*}{ High } & 15 & $8.85 \pm 0.28^{C}$ & $2.50 \pm 0.22^{\mathrm{C}}$ & $100 \pm 0.00^{\mathrm{A}}$ \\
\hline & 20 & $10.7 \pm 0.21^{\mathrm{B}}$ & $4.51 \pm 0.12^{\mathrm{B}}$ & $100 \pm 0.00^{\mathrm{A}}$ \\
\hline & 26 & $10.5 \pm 0.13^{\mathrm{B}}$ & $4.24 \pm 0.14^{\mathrm{B}}$ & $93.3 \pm 0.00^{\mathrm{B}}$ \\
\hline & 35 & $12.5 \pm 0.30^{\mathrm{A}}$ & $6.42 \pm 0.13^{\mathrm{A}}$ & $100 \pm 0.00^{\mathrm{A}}$ \\
\hline & 12 & $10.0 \pm 0.15^{\mathrm{ab}}$ & $3.77 \pm 0.23^{\mathrm{ab}}$ & $97.8 \pm 2.22^{\mathrm{a}}$ \\
\hline \multirow[t]{4}{*}{ Zero } & 15 & $9.41 \pm 0.07^{b}$ & $3.11 \pm 0.07^{b}$ & $95.6 \pm 2.22^{\mathrm{a}}$ \\
\hline & 20 & $11.7 \pm 0.33^{\mathrm{a}}$ & $5.52 \pm 0.44^{\mathrm{a}}$ & $86.7 \pm 3.85^{\mathrm{a}}$ \\
\hline & 26 & $11.2 \pm 0.57^{\mathrm{a}}$ & $4.78 \pm 0.56^{\mathrm{ab}}$ & $48.9 \pm 4.44^{b}$ \\
\hline & 35 & $11.6 \pm 0.62^{\mathrm{a}}$ & $5.60 \pm 0.63^{\mathrm{a}}$ & $20.0 \pm 10.2^{c}$ \\
\hline \multicolumn{5}{|l|}{ ANOVA, $\operatorname{Pr}>F$} \\
\hline \multicolumn{2}{|c|}{ Protein $\times$ Exchange } & 0.0108 & 0.0131 & $<0.0001$ \\
\hline
\end{tabular}

${ }^{2}$ Significant differences for means within experimental groups of the same culture system are indicated with different superscripts (One -way ANOVA by protein level, SNK $P<0.05$ ).

Table 4. Effects of dietary protein and water exchange on growth and survival for 23 day growth trial with juvenile shrimp stocked at $6.21 \mathrm{~g} \pm 0.22(\mathrm{SD})$. Values represent means $\pm S E$ for 3 replicates.

zero exchange, $\mathrm{pH}$ remained above 7.60. At day $4, \mathrm{KH}$ was higher at zero exchange ( $K H=7.79$ to 7.94 ) than high exchange $(K H=7.78)$. However, like $\mathrm{pH}, \mathrm{KH}$ also decreased during the growth trial at zero exchange for 26 and $35 \%$ protein to levels of 7.23 and 6.87 , respectively.

\subsection{Postlarvae}

\section{2..1. Shrimp performance}

FBW, WG and survival of $L$. vannamei fed the five diets at high and zero exchange are given in Table 5 and Fig. 4 for the growth trial stocked with postlarval shrimp. For all parameters, the interaction between dietary protein level and water exchange was significant $(P<0.0001)$. A posteriori comparisons of means between protein levels within water exchange are shown in Table 5. A posteriori comparisons of means between water exchange rates within protein levels are shown in Fig. 4.

At high exchange, survival did not differ between protein levels $(P=0.7114)$ and mean survival was $93.7 \%$. For $35 \%$ protein at zero exchange, survival $(49.7 \%)$ was lower than survivals for 12 to $26 \%$ protein (93.3 to $100 \%$ ) (Table 5). For protein levels from 12 to $26 \%$, survival did not differ between high and 

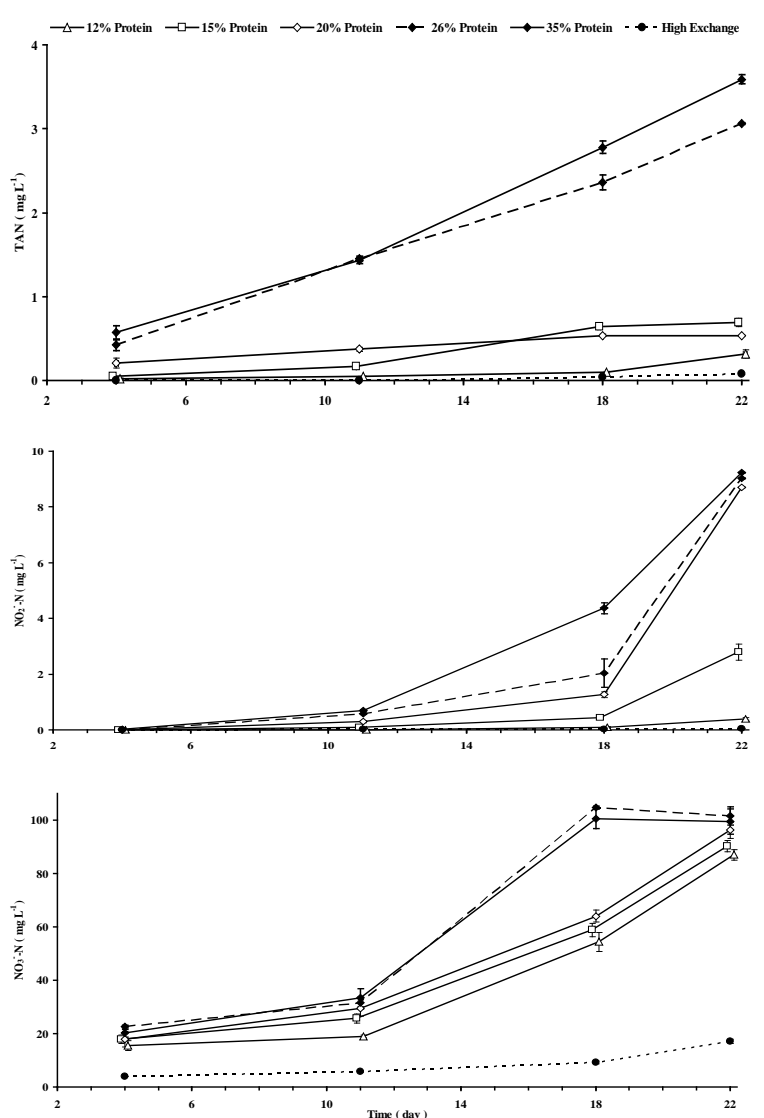

Fig. 2. Effects of dietary protein on levels of total ammonia nitrogen (TAN), nitrite nitrogen $\left(\mathrm{NO}_{2}-\mathrm{N}\right)$ and nitrate nitrogen $\left(\mathrm{NO}_{3}-N\right)$ for zero exchange in 23 day growth trial with juvenile shrimp stocked at $6.21 \mathrm{~g} \pm 0.22$ (SD). For zero exchange, values are means $( \pm S . E)$ of three replicate tanks per sampling time at each protein level. The high exchange represents combined observations of all protein levels at high water exchange $(n=5)$.

zero exchange. However, for $35 \%$ protein, survival was lower $(P<0.0001)$ at zero than at high exchange (Fig. 4).

At high exchange, FBW and WG for $20 \%$ protein was not significantly $(P>0.05)$ different with that for $35 \%$ protein, but FBW for both 20 and 35\% protein and $\mathrm{WG}$ for $35 \%$ protein were greater than FBW and WG for other protein levels $(P<$ $0.05)$. At zero exchange, growth was greatest at $20 \%$ protein level (Table 5). In comparing effects of water exchange with each level of protein, growth was greater at zero exchange than at high exchange for all protein levels except $35 \%$ (Fig. 4).

\section{2..2. Water quality}

DO was lower $(P=0.0483)$ in zero exchange treatments (mean \pm standard deviation of $5.75 \pm 0.63 \mathrm{mg} / \mathrm{l}, n=24$ ) than in high exchange treatments $(6.05 \pm 0.34 \mathrm{mg} / \mathrm{l}, n=24)$.
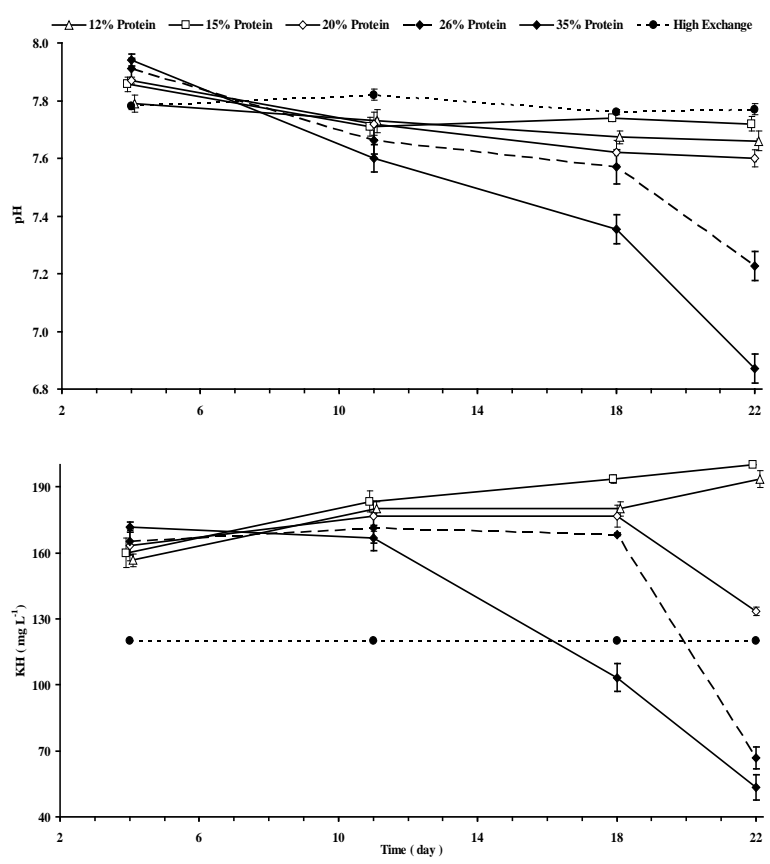

Fig. 3. Effects of dietary protein on $\mathrm{pH}$ and total alkalinity (KH) for zero exchange in 23 day growth trial with juvenile shrimp stocked at $6.21 \mathrm{~g} \pm 0.22(\mathrm{SD})$. For zero exchange, values are means $( \pm S . E)$ of three replicate tanks per sampling time at each protein level. The high exchange represents combined observations of all protein levels at high water exchange $(n=$ $5)$.

Salinity was higher $(P<0.0001)$ in zero exchange treatments $(38.6 \pm 1.03 \mathrm{ppt}, n=24)$ than in high exchange treatments $(36.9 \pm 1.03 \mathrm{ppt}, n=24)$. Temperature was lower $(P=0.0109)$ in zero exchange treatments $\left(27.4 \pm 1.9^{\circ} \mathrm{C}\right.$, $n=24)$ than in high exchange treatments $\left(28.81 .9^{\circ} \mathrm{C}, n=\right.$ $24)$. Though there were differences in DO, salinity and temperature between the high and zero exchange treatments, all means were within acceptable levels for growth and survival.

At zero exchange, weekly means and standard errors of TAN, $\mathrm{NO}_{2}-\mathrm{N}$ and $\mathrm{NO}_{3}-\mathrm{N}$ are shown in Fig. 5 for each level of protein. In addition, water quality differences between diets were not significant at high exchange. Values for all protein levels at high exchange were pooled and shown as high exchange in Fig. 5. At zero exchange, TAN increased from day 12 through 21 for both 26 and $35 \%$ protein but did not differ between days 21 and 25 . For high exchange and protein levels of 12 to $20 \%$ at zero exchange, TAN levels remained below $0.45 \mathrm{mg} / \mathrm{l}$ through 25 days. At zero exchange, $\mathrm{NO}_{2}-\mathrm{N}$ levels increased to a maximum at day 25 for 26 and $35 \%$ protein levels. For high exchange and protein levels of 12 to $20 \%$ at zero exchange, $\mathrm{NO}_{2}-\mathrm{N}$ levels remained below $0.45 \mathrm{mg} / \mathrm{l}$ through 25 days. At zero exchange, $\mathrm{NO}_{3}-\mathrm{N}$ levels increased from day 17 to 25 for all 


\begin{tabular}{|c|c|c|c|c|}
\hline Water exchange & Protein (\%) & $\mathrm{FBW}(\mathrm{g})^{1}$ & WG $(g)^{1}$ & Survival (\%) \\
\hline & 12 & $1.38 \pm 0.06^{\mathrm{C} 2}$ & $1.17 \pm 0.05^{\mathrm{C} 2}$ & $90.0 \pm 6.83$ \\
\hline \multirow{5}{*}{ High } & 15 & $1.18 \pm 0.02^{\mathrm{D}}$ & $0.96 \pm 0.02^{\mathrm{D}}$ & $97.0 \pm 3.03$ \\
\hline & 20 & $1.96 \pm 0.07^{\mathrm{A}}$ & $1.74 \pm 0.06^{\mathrm{AB}}$ & $93.3 \pm 4.22$ \\
\hline & 26 & $1.76 \pm 0.06^{\mathrm{B}}$ & $1.56 \pm 0.06^{\mathrm{B}}$ & $91.7 \pm 3.07$ \\
\hline & 35 & $2.01 \pm 0.11^{\mathrm{A}}$ & $1.80 \pm 0.11^{\mathrm{A}}$ & $96.7 \pm 2.11$ \\
\hline & 12 & $1.67 \pm 0.03^{\mathrm{c}}$ & $1.46 \pm 0.03^{\mathrm{c}}$ & $93.3 \pm 2.11^{\mathrm{a}}$ \\
\hline \multirow[t]{4}{*}{ Zero } & 15 & $1.98 \pm 0.12^{\mathrm{bc}}$ & $1.78 \pm 0.12^{\mathrm{bc}}$ & $100 \pm 0.00^{\mathrm{a}}$ \\
\hline & 20 & $2.93 \pm 0.15^{\mathrm{a}}$ & $2.71 \pm 0.15^{\mathrm{a}}$ & $93.3 \pm 6.67^{\mathrm{a}}$ \\
\hline & 26 & $2.35 \pm 0.07^{b}$ & $2.14 \pm 0.07^{\mathrm{b}}$ & $95.3 \pm 3.34^{\mathrm{a}}$ \\
\hline & 35 & $2.04 \pm 0.14^{\text {bc }}$ & $1.82 \pm 0.14^{\mathrm{bc}}$ & $49.7 \pm 5.18^{b}$ \\
\hline \multicolumn{5}{|l|}{ ANOVA, $\operatorname{Pr}>F$} \\
\hline \multicolumn{2}{|c|}{ Protein $\times$ Exchange } & $<0.0001$ & $<0.0001$ & $<0.0001$ \\
\hline
\end{tabular}

Table 5. Effects of dietary protein and water exchange on growth and survival for 26 day growth trial with postlarval shrimp stocked at $0.22 \mathrm{~g} \pm 0.02(\mathrm{SD})$. Values represent means $\pm S E$ for 6 replicates.

protein levels. At day $25, \mathrm{NO}_{3}-\mathrm{N}$ levels ranged from 49.68 to $69.29 \mathrm{mg} / \mathrm{l}$ for all protein levels at zero exchange.

Means and standard errors for $\mathrm{pH}$ and $\mathrm{KH}$ are shown in Figure 6 for each protein level at zero exchange, and for pooled values at high exchange. From day 17 to $25, \mathrm{pH}$ decreased from 7.9 to 7.0 for $35 \%$ protein at zero exchange. For high exchange and other protein levels at zero exchange, $\mathrm{pH}$ remained above 7.55. At day $12, \mathrm{KH}$ was higher at zero exchange $(K H=140.00$ to $186.67)$ than high exchange $(K H=120.00)$. However, like $\mathrm{pH}, \mathrm{KH}$ also decreased during the growth trial at zero exchange for 26 and $35 \%$ protein to levels of 140.00 and 36.67, respec- tively. For other protein levels at zero exchange, KH remained above 140.00 .

\section{Discussion}

In both growth trials, shrimp were fed an excess amount of feed as indicated by the high feed to weight gain ratios for treatments with the highest growth rates. The highest growth rates were obtained with $35 \%$ protein diet at high exchange for trials stocked with both juvenile and postlarval shrimp. These ratios were 2.68 for juvenile stocked shrimp with a weight gain of $6.42 \mathrm{~g}$ and 3.31 for postlarval stocked shrimp with a weight gain of 1.80 

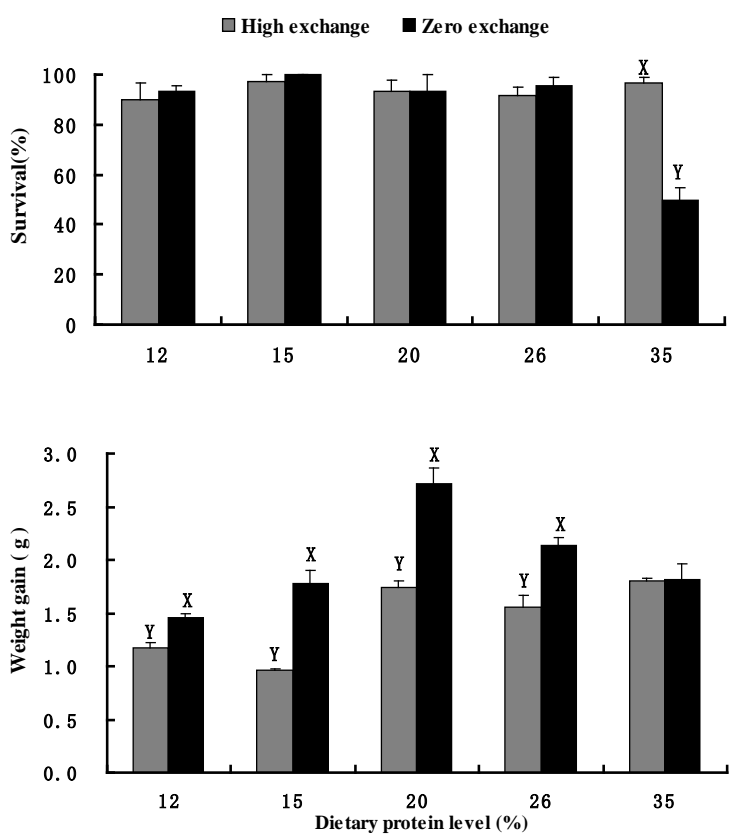

Fig. 4. Effects of dietary protein and water exchange on survival and weight gain (WG) for 26 day growth trial with postlarval shrimp stocked at $0.22 \mathrm{~g} \pm 0.02$ (SD). Values represent means $\pm S E$ for 6 replicates. Significant differences between water exchange within each level of protein are indicated with different letters (One-way ANOVA, SNK $P<0.05$ ).

g. These ratios were even greater in other treatments in which shrimp exhibited less growth. Shrimp at zero exchange were fed the same amount of feed as those at high exchange.

The quality of the shrimp and culture conditions used in these growth trials were adequate to detect treatment effects. In high exchange treatments, in which culture conditions were adequate for high growth and survival, survival was up to $100 \%$ and weight increase up to $103 \%$ of stocking weights for juvenile shrimp. For postlarvae, survival was up to $97 \%$ and weight increase up to $818 \%$.

Increased growth of juvenile shrimp with protein levels from 12 to $35 \%$ at high water exchange rates has been previously reported (Cousin et al., 1991; Smith et al., 1984). In this study, growth also increased with protein level from $12 \%$ to $20 \%$ for both juvenile shrimp and postlarvae at high exchange. For juvenile shrimp at high exchange, a posteriori comparison of means indicated that growth was higher with $35 \%$ protein than either 20 or $26 \%$ protein. For postlarvae at high exchange, a priori contrasts of means using the SAS GLM procedure for one-way ANOVA suggested that growth with $20 \%$ protein did not differ $(P=0.0785)$ from growth with 26 and $35 \%$ protein. Growth of shrimp was greater at zero exchange than that in tanks at high exchange for juvenile shrimp with $12 \%$ protein and for postlarvae with 12 to $26 \%$ protein.

In this study, one explanation for enhanced growth at low
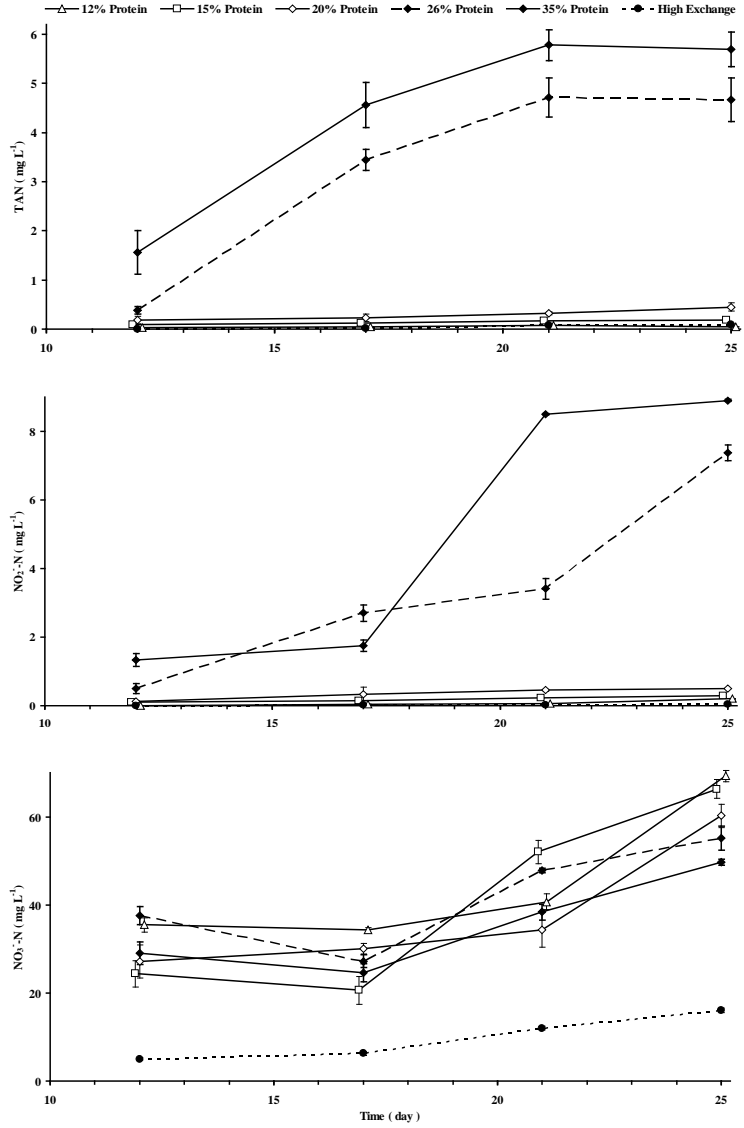

Fig. 5. Effects of dietary protein on levels of total ammonia nitrogen (TAN), nitrite nitrogen $\left(\mathrm{NO}_{2}-\mathrm{N}\right)$ and nitrate nitrogen $\left(\mathrm{NO}_{3}-\mathrm{N}\right)$ for zero exchange in 26 day growth trial with postlarval shrimp stocked at $0.22 \mathrm{~g} \pm 0.02(\mathrm{SD})$. For zero exchange, values are means $( \pm S . E)$ of three replicate tanks per sampling time at each protein level. The high exchange represents combined observations of all protein levels at high exchange $(n=5)$.

water exchange is that biofloc developed in culture tanks. Improved growth and feed utilization in the presence of biofloc has been reported for L. vannamei (Wasielesky et al., 2006; Xu et al., 2012a; Xu and Pan, 2012b; Xu et al., 2012c), P. monodon (Arnold et al., 2009), P. semisulcatus (Megahed, 2010) and $F$. brasiliensis (Emerenciano et al., 2012). Biofloc has been suggested to provide a supplemental food source to shrimp (Burford et al., 2004; Kuhn et al., 2008; Megahed, 2010). Biofloc can be consumed and provide important sources of nutrients (Burford et al., 2003; 2004; Tacon et al., 2002; Wasielesky et al., 2006; Xu et al., 2012a; Xu and Pan, 2012b; Xu et al., 2012c). Moreover, biofloc, which exhibits high protease and amylase activities (Xu et al., 2012b), can contribute to digestion and utilization of shrimp diet. In addition, biofloc can stimulate pro- 

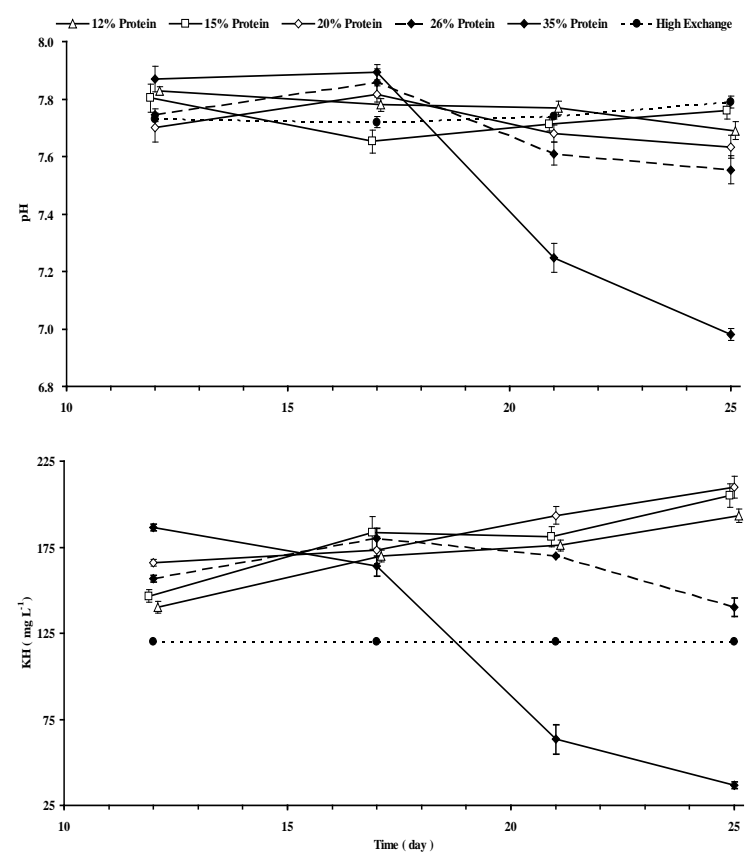

Fig. 6. Effects of dietary protein on $\mathrm{pH}$ and total alkalinity $(\mathrm{KH})$ for zero exchange in 26 day growth trial with postlarval shrimp stocked at $0.22 \mathrm{~g} \pm 0.02$ (SD). For zero exchange, values are means $( \pm S . E)$ of three replicate tanks per sampling time at each protein level. The high exchange represents combined observations of all protein levels at high exchange $(n=5)$.

duction of digestive enzymes in shrimp (Xu et al., 2012a; Xu and Pan, 2012b; Xu et al., 2012c).

In both growth trials of this study, high turbidity and brown color in zero exchange culture tanks suggested the presence of biofloc. Although culture tanks were not inoculated with biofloc prior to stocking, biofloc developed rapidly, and visual observations of shrimp on the bottom of culture tanks were impossible within one week of stocking. Even though biofloc density was not quantified, and composition was not determined in this study, it is unlikely that biofloc density, composition and nutritional value were stable throughout either growth trial. Nonetheless, growth was enhanced at zero exchange in both trials.

In this study, the growth at zero exchange was enhanced in smaller shrimp over a wider protein range (12 to 26\%) than in larger shrimp (only $12 \%$ protein). Burford et al. (2004) reported that in L. vannamei, nitrogen retention contributed by natural biofloc was lower in 5 and $9 \mathrm{~g}$ shrimp than in smaller $1 \mathrm{~g}$ shrimp. Xu et al. (2012c) suggested that larger shrimp ingested fewer particles and sizes of biofloc, which produced a smaller contribution to growth.

For both growth trials in this study, salinity was higher, and DO and temperature were lower at zero exchange than at high exchange. Emerenciano et al. (2012) attributed higher salinity and lower DO at zero exchange to evaporation without ex-

\begin{tabular}{ccccc}
\hline \multirow{2}{*}{ Protein (\%) } & \multicolumn{2}{c}{ Juvenile shrimp } & \multicolumn{2}{c}{ Postlarvae } \\
\cline { 2 - 5 } & Feed/tank (g) & $\begin{array}{c}\text { Total protein } \\
\text { nitrogen }(\mathrm{mg} / \mathrm{l})\end{array}$ & Feed/tank (g) & $\begin{array}{c}\text { Total protein } \\
\text { nitrogen (mg/l) }\end{array}$ \\
\hline 12 & 257.98 & 50.03 & 56.81 & 54.54 \\
15 & 257.98 & 62.54 & 56.81 & 68.17 \\
20 & 257.98 & 83.39 & 56.81 & 90.90 \\
26 & 257.98 & 108.4 & 56.81 & 118.2 \\
35 & 257.98 & 145.9 & 56.81 & 159.1 \\
\hline
\end{tabular}

Table 6. Amount of total protein nitrogen added to culture tanks for shrimp stocked as juveniles $(6.21 \mathrm{~g} \pm 0.22(\mathrm{SD}))$ and postlarvae $0.22 \mathrm{~g} \pm 0.02$ (SD). Total protein nitrogen is expressed as concentration in culture tanks.

change and respiration of heterotrophic communities. In this study, where enhanced growth was observed in treatments with zero exchange, the increased growth could not be attributed to differences in salinity, DO or temperature because all of these parameters were more conducive to growth at high exchange than at zero exchange.

In this study, higher levels of TAN, $\mathrm{NO}_{2}-\mathrm{N}$ and $\mathrm{NO}_{3}-\mathrm{N}$ in zero exchange culture tanks were observed in this study with increased levels of protein in the feed. In a zero-water (biofloc) exchange system, Moeckel et al. (2012) reported that in a zerowater (biofloc) exchange system, the greater amount of protein added, the lower the water quality. Avnimelech and Ritvo (2003) found that about $75 \%$ of the nitrogen in the feed is released to the water. At zero exchange, nitrogen in the water at zero exchange was either directly (from bacterial catabolism of uneaten diet) or indirectly (from catabolism of consumed diet by shrimp) dependent upon the protein in the feed. The calculated amounts of protein nitrogen added to the culture tanks as feed were calculated from the percentages of protein and amounts of feed and expressed as concentrations shown in Table 6. Despite differences in culture tank volumes, stocking densities, sizes of shrimp, and feed rates, calculated concentrations of total feed the total protein nitrogen fed to shrimp were similar in the two growth trials. The concentrations of total protein nitrogen increased with increased levels of protein (Table 6). And about $75 \%$ of the nitrogen in the feed is released to the water (Avnimelech and Ritvo, 2003).

At zero exchange, high levels of TAN and $\mathrm{NO}_{2}-\mathrm{N}$ for the 26 and $35 \%$ protein diets in the juvenile shrimp growth trial and for the $35 \%$ protein diet in the postlarval growth trial may have caused the decreased survival (less than 50\%). The higher nitrite level (above $5 \mathrm{mg} / \mathrm{l}$ ) at end of the experiment may have caused a depression in immune ability (Tseng and Chen, 2004), which may resulted in the lower survivals observed in this study. Decreased $\mathrm{pH}$ and $\mathrm{KH}$, which were observed in this study, can limit the ability of nitrifying bacteria to oxidize nitrite to nitrate, 
and result in high nitrite levels (Rittmann and McCarty, 2001; Avnimelech, 2012).

This study suggested that a $20 \%$ protein diet, which contained $25.3 \%$ marine animal meals $(19.3 \%$ squid muscle meal and $6.0 \%$ fish meal), was nutritionally adequate for growth and survival of postlarval and juvenile shrimp in a zero exchange culture system. This $20 \%$ protein diet contained $16 \%$ squid protein, $4 \%$ fish protein and $0 \%$ non-marine protein. In the growth trial stocked with postlarval shrimp with no water exchange, maximum growth was obtained with $20 \%$ protein diet. In the growth trial stocked with juvenile shrimp in culture tanks with no water exchange, growth did not differ between 20, 26 and $35 \%$ protein diets. Other studies that have reported the use of lower protein diets without reduced growth have used protein levels down to $18 \%$. Decamp et al. (2002) reported no differences between the growth performances of L. vannamei fed on $25 \%$ or $35 \%$ protein diet in unfiltered pond water. Weight gain and survival of L. vannamei were also not different when feeding commercial diets with $25 \%, 30 \%, 35 \%$ and $40 \%$ protein in a zero water exchange system (Gómez-Jiménez et al., 2005). Xu et al. (2012a) found that the dietary protein level of $L$. vannamei juveniles could be reduced to $25 \%$ without affecting shrimp growth in a zero-water exchange biofloc-based system. Velasco and Lawrence (2000) reported no difference in L. vannamei postlarvae growth between 18 and $25 \%$ protein diets in static tanks.

\section{Conclusions}

In zero water exchange shrimp culture systems, lower protein diets can replace commonly used high protein (35\%) diet and obtain high growth rate for both small (IBW: $0.22 \mathrm{~g}$ ) and larger (IBW: $6.21 \mathrm{~g}$ ) L. vannamei. For the conditions of this experiment, $20 \%$ protein diet, which contained $25.3 \%$ marine animal meals, was adequate for shrimp growth, survival and water quality in the absence of water exchange. Future research is warranted to determine if biofloc is responsible for benefits observed in zero exchange, and if biofloc contributes other nutrients (e.g. vitamins, phospholipids, cholesterol, etc.) to the dietary requirements of shrimp. The mechanism by which biofloc can increase shrimp growth needs to be fully understood.

\section{Acknowledgements}

The research was funded by Project R-9500, Texas A\&M AgriLife Research, Texas A\&M University System and China Scholarship Council. The authors also would like to acknowledge Jack Crockett, Jessica Morgan and Ivy McClellan for reviewing this publication.

\section{References}

APHA. 2005. Standard Methods for the Examination of the Water and Wastewater, 21st ed. American Public Health Association, Washington, DC, USA.
Arnold, S.J., Coman, F.E., Jackson, C.J., and Groves, S.A. 2009. Highintensity, zero water exchange production of juvenile tiger shrimp, Penaeus monodon: an evaluation of artificial substrates and stocking density. Aquaculture 293, 42-48.

Asaduzzaman, M., Wahab, M.A., Verdegem, M.C.J., Huque, S., Salam, M.A., and Azim, M.E. 2008. C/N ratio control and substrate addition for periphyton development jointly enhance freshwater prawn Macrobrachium rosenbergii production in ponds. Aquaculture 280, 117123.

Avnimelech, Y. 2012. Biofloc Technology A Practical Guide Book, 2d Edition. The World Aquaculture Society, Baton Rouge.

Avnimelech, Y., and Ritvo, G. 20003. Shrimp and fish pond soils: Processes and management. Aquaculture 220, 549-567.

Bender, J., Lee, R., Sheppard, M., Brinkley, K., Philips, P., Yeboah, Y., and Wah, R.C. 2004. A waste effluent treatment system based on microbial mats for black sea bass Centropristis striata recycled-water mariculture. Aquacultural Engineering 31, 73-82.

Browdy, C.L., Bratvold, D., Stokes, A.D., and Mcintosh, R.P. 2001. Perspectives on the application of closed shrimp culture systems, in E.D. Jory and C.L. Browdy (eds), The New Wave, Proceedings of the Special Session on Sustainable Shrimp Culture, The World Aquaculture Society, Baton Rouge, 20-34.

Burford, M.A., Thompson, P.J., McIntosh, R.P., Bauman, R.H., and Pearson, D.C. 2003. Nutrient and microbial dynamics in highintensity, zero-exchange shrimp ponds in Belize. Aquaculture. 219, 393-411.

Burford, M.A., Thompson, P.J., McIntosh, R.P., Bauman, R.H., and Pearson, D.C. 2004. The contribution of flocculated material to shrimp (Litopenaeus vannamei) nutrition in a high-intensity, zeroexchange system. Aquaculture. 232, 525-537.

Cohen, J., Samocha, T.M., Fox, J.M., Gandy, R.L., and Lawrence, A.L. 2005. Characterization of water quality factors during intensive raceway production of juvenile $L$. vannamei using limited discharge and biosecure management tools. Aquacultural Engineering 32, 425-442.

Cousin, M., Cuzon, G., Blanchet, E., and Ruelle, F. 1991. Protein requirements following an optimum dietary energy to protein ration for Penaeus vannamei juveniles., in S.J. Kaushik and P. Liquet (eds.), Fish Nutrition in Practice, Institut National de la Recherche Agronomique, Paris, 599-567.

Crab, R., Chielens, B., Wille, M., Bossier, P., and Verstraete, W. 2013. The effect of different carbon sources on the nutritional value of bioflocs, a feed for Macrobrachium rosenbergii postlarvae. Aquaculture Research 41, 559-567.

Crockett, J., Lawrence, A.L., and Kuhn, D.D. 2013. Shallow nursery system uses bioreactor concept for production of juvenile shrimp. Global Aquaculture Advocate 16(3), 72-75.

De Schryver, P., Crab, R., Defoirdt, T., Boon, N., and Verstraete, W. 2008. The basics of bioflocs technology: the added value for aquaculture. Aquaculture 277, 125-137.

Decamp, O., Conquest, L., Forster, I., and Tacon, A.G.J. 2001. The nutrition and feeding of marine shrimp within zero-water exchange aquaculture production system: role of Eukaryotic microorganisms, in C.S. Lee and P. O'Bryen (eds), Microbial Approaches to Aquatic Nutrition within Environmentally Sound Aquaculture Production Systems, The World Aquaculture Society, Baton Rouge, 79-86.

Emerenciano, M., Ballester, E.L.C., Cavalli, R.O., and Wasielesky, W. 2012. Biofloc technology application as a food source in a limited water exchange nursery system for pink shrimp Farfantepenaeus 
brasiliensis (Latreille, 1817). Aquaculture Research 43, 447-457.

Gómez-Jiménez, S., González-Félix, M.L., Perez-Velazquez, M., Trujillo-Villalba, D.A., Esquerra-Brauer, I.R., and BarrazaGuardado, R. 2005. Effect of dietary protein level on growth, survival and ammonia efflux rate of Litopenaeus vannamei (Boone) raised in a zero water exchange culture system. Aquaculture Research 36, 834-840.

Hari, B., Kurup, B.M., Varghese, J.T., Schrama, J.W., and Verdegem, M.C.J. 2004. Effects of carbohydrate addition on production in extensive shrimp culture systems. Aquaculture 241, 179-194.

Hari, B., Kurup, B.M., Varghese, J.T., Schrama, J.W., and Verdegem, M.C.J. 2006. The effect of carbohydrate addition on water quality and the nitrogen budget in extensive shrimp culture systems. Aquaculture 252, 248-263.

Hopkins, J.S., Sandifer, P.A., and Browdy, C.L. 1995. Effect of two protein levels and feed rate combinations on water quality and production of intensive shrimp ponds operated without water exchange. Journal of the World Aquaculture Society 26, 93-97.

Horowitz, A. and Horowitz, S. 2001. Disease control in shrimp aquaculture from a microbial ecology perspective., in C.L. Browdy and C.L. Jory (eds.), Proceedings of the Special Session on Sustainable Shrimp Farming, The World Aquaculture Society, Baton Rouge, 199-218.

Hu, Y., Tan,B., Mai, K., Ai, Q., Zheng, S., and Cheng, K. 2008. Growth and body composition of juvenile white shrimp, Litopenaeus vannamei, fed different ratios of dietary protein to energy. Aquaculture Nutrition 14, 499-506.

Kuhn, D.D., Boardman, G.D., Craig, S.R., Flick, G.J., and McLean, E. 2008. Use of microbial flocs generated from tilapia effluent as a nutritional supplement for shrimp, Litopenaeus vannamei, in recirculating aquaculture systems. Journal of the World Aquaculture Society 39, 72-82.

Kureshy, N. and Davis, D.A.. 2002. Protein requirement for maintenance and maximum weight gain for the Pacific white shrimp, Litopenaeus vannamei. Aquaculture 204, 125-143.

Lawrence, A.L., Castille, F.L., Samocha, T., and Velasco, M. 2001. "Environmentally friendly" or "least polluting" feed and feed management for aquaculture., in C.L. Browdy and D.E. Jory (eds.), The New Wave, Proceedings of the Special Session on Sustainable Shrimp Culture, Aquaculture 2001, The World Aquaculture Society, Baton Rouge, 84-95.

Megahed, M.E. 2010 The effect of microbial biofloc on water quality, survival and growth of the green tiger shrimp (Penaeus Semisulcatus) fed with different crude protein levels. Journal of the Arabian Aquaculture Society 5, 119-142.

Merrill, A.L., and Watt, B.K. 1973. Energy value of foods: basis and derivation. In United States Department of Agriculture (USDA), Handbook No. 74.

Moeckel, J.L., Lawrence, A.L., Crockett, J., Lingenfelter, B.A., Patnaik, S., and Pollack, J.B. 2012. Effect of Dietary Protein on Growth and Survival of Juvenile Litopenaeus vannamei in a Zero Water (Biofloc) Exchange System. 9th International Conference on Recirculating Aquaculture 173-210.

Rittmann, B.E. and McCarty, P.L. 2001. Chapter 9: Nitrification, in Environmental Biotechnology: Principles and Applications, McGrawHill Companies, INC., New York, 470-496.

Smith, L.L., Lee, P.G., Lawrence, A.L., and Strawn, K. 1984. Growth and digestibility by three sizes of Penaeus vannamei Boone: effects of dietary protein level and protein source, Aquaculture 46, 85-96.
Tacon, A.G.J., Cody, J.J., Conquest, L.D., Divakaran, S., Forster, I.P., and Decamp, O.E. 2002. Effect of culture system on the nutrition and growth performance of Pacific white shrimp Litopenaeus vannamei (Boone) fed different diets, Aquaculture Nutrition 8, 121-139.

Tseng, I-T., and Chen, J.C. 2004. The immune response of white shrimp Litopenaeus vannamei and its susceptibility to Vibrio alginolyticus under nitrite stress, Fish \& Shellfish Immunology 17, 325-333.

Velasco, M., and Lawrence, A.L. 2000. Recirculating and static shrimp culture system, Global Aquaculture Advocate 3(3), 60.

Wasielesky, W. Jr., Atwood, H., Stokes, A., and Browdy, C.L. 2006. Effect of natural production in a zero exchange suspended microbial floc based super-intensive culture system for white shrimp Litopenaeus vannamei. Aquaculture 258, 396-403.

Xu, W.J., Pan, L.Q., Zhao, D.H., and Huang, J. 2012a. Preliminary investigation into the contribution of bioflocs on protein nutrition of Litopenaeus vannamei fed with different dietary protein levels in zero-water exchange culture tanks. Aquaculture 350-353, 147-153.

Xu, W.J., and Pan, L.Q. 2012b. Effects of bioflocs on growth performance, digestive enzyme activity and body composition of juvenile Litopenaeus vannamei in zero-water exchange tanks manipulating $\mathrm{C} / \mathrm{N}$ ratio in feed. Aquaculture 356-357, 147-152.

Xu, W.J., Pan, L.Q., Sun, X.H., and Huang, J. 2012c. Effects of bioflocs on water quality, and survival, growth and digestive enzyme activities of Litopenaeus vannamei (Boone) in zerowater exchange culture tanks. Aquaculture Research. Available at: http://dx.doi.org/10.1111/j.1365-2109.2012.03115.x. 